\title{
Development of Color Notation for Kindergarten Children
}

\author{
Suryadi \\ Early Childhood Education \\ Universitas Negeri Malang \\ Malang, Indonesia \\ suryadi.fip@um.ac.id
}

\begin{abstract}
This study aims to produce products in the form of media that can help children understand, read, and memorize the music notation. Development used in this research is Dick \& Carey model from step 1 to step 9. Based on the description of data analysis from material experts, media experts, learning experts, and the results of the trial tests, it can be stated that the music notation media for kindergartenaged children that has been developed is very feasible and effective to use. The total score for this product was 381 or in percentage was $98 \%$ and was categorized as excellent. This indicates that the products produced are very feasible and very effective so that development needs to be carried out.
\end{abstract}

Keywords-music, color notation, kindergarten

\section{INTRODUCTION}

Kindergartens as Formal PAUD institutions should function to develop all the potential that their students have. A number of studies show that the development of children's intelligence at the age of 4 to 6 years has increased from $50 \%$ to $80 \%$ because at this age children experience a sensitive period of maturation of physical and psychological functions that are ready to respond to the stimulus provided by the environment. This period is ideal for putting the first and foremost foundation in developing all the potential of children including the development of potential in musical abilities.

Kindergarten teachers as facilitators in the development of children's potential are expected to equip themselves with various fields of knowledge and potential development of children's potential so that they can carry out their roles well, which is helping to make it easier for children to learn. In other words, kindergarten teachers must have good competence and qualifications that are appropriate to their fields. Without sufficient supplies and having the right methods, models, and media, kindergarten teachers will not be able to develop children's potential optimally.

From the result of a short interview with several kindergarten teachers and heads of kindergartens and administrators in Malang, it was shown that in general, kindergarten teachers have difficulty in increasing the effectiveness of learning in their respective kindergartens in the field of music, especially in terms of recognition and understanding of music notation, especially as an introduction in understand beam notation. This situation is due to the lack of knowledge and skills of teachers about the development of music, especially music notation, which can enable children to be active, creative, and fun in their learning activities, so this condition is quite detrimental for children when children must develop optimally in the ideal age range in their growth.

In general, kindergarten teachers do not have good music competence, so they often experience difficulties when faced with the task of delivering music learning material, especially in terms of introducing and understanding music notation to children especially about beam notation. Likewise children will find it difficult to receive material from the teacher. This will be even worse when a teacher turns out to have no educational qualifications as a kindergarten teacher and even has a non-educational background.

Based on the results of the situation analysis, a research was proposed on the "Development of Music Notation for Kindergarten Children" whose results are expected to improve the effectiveness and quality, as well as the right way in implementing learning in kindergarten, especially in terms of introducing and understanding music notation, especially as an introduction in knowing and understanding beam notation.

The method in question is the development of musical notation using color notation with a tone region boundary between "do" to "la" according to the characteristics of music for early childhood according to McPherson, as an effort to provide alternative solutions to problems faced by kindergarten teachers related to the existences of musical notation symbols, especially beam notation [1]. Color notation is the development of existing notation by changing its appearance to color to symbolize tone or solmization. This concept was adapted from Mary Bassano's theory of the psychology of music and color [2] While, the tone value used still follows the applicable tone value as described by Karl Edmund Prier [3].

In this way all kindergarten children will easily understand the meaning of symbolizing music notation, especially as a basis for understanding beam notation. Furthermore, it is expected to make children active, creative, and fun in learning activities which ultimately help facilitate children in learning music in order to support the achievement of the objectives of kindergarten education in children, especially the musical field as part of efforts to increase multiple intelligence.

\section{METHOD}

\section{A. Development Model}

The development of music notation media for kindergartens (TK) is an experimental study using a preexperimental design of one group pretest-posttest design, 
with a quantitative approach. That is done by describing the data in the form of numbers that are quantitative in nature so that they can be used to predict conditions that are wider than the population and the future. Quantitative approaches can be interpreted as a research approach based on the philosophy of positivism, which is used to examine certain populations or samples. The data collection technique uses research instruments where the data analysis is quantitative / statistics directed to answer the formulation of the problem and the proposed hypothesis [4].

The method used in this study is a research method development or R \& D (Research and Development), the research achievements eventually produce a product, whether the product is the development of existing and new product altogether. This study aims to develop a media in the form of new music notation so that it can help facilitate kindergarten children in recognizing and understanding the meaning of symbolizing notation. The resulting product is a musical notation media in the form of color notation.

The Dick and Carey model consists of 10 steps in conducting research and development, namely: (1) identifying instructional goals or analyzing needs and goals, (2) conducting instructional analysis or conducting learning analysis, (3) identifying entry behaviors and learner characteristics and context (4) writing performance objectives or formulating learning goals, (5) developing criterion retested tests or developing assessment instruments, (6) developing an instructional strategy or developing learning strategies, (7) developing and selecting instruction or develop and choose teaching materials, (8) designing and conducting the formative evaluation or designing and developing formative evaluations (individual testing, small group trials with 6-8 subjects, field trials with 15-30 subjects), (9) revising instruction or make revisions, (10) summative conduction or design and develop summative evaluation.

By referring to Dick and Carey's development and research model, out of the ten existing development steps, the researchers took nine steps in this process. This was done because as stated by Setyosari that, "for development purposes researchers usually only use it up to the ninth step, which is formative evaluation where the design, process, or program is considered complete"[5].

\section{B. Product Trial}

This product trial was conducted to collect data used as a basis for determining the feasibility and effectiveness of the product being developed. In this section the things described are: (1) Trial design, (2) Test subjects, (3) Data types, (4) Data collection instruments, and (5) Data analysis techniques, which are used as a basis for setting levels attractiveness, level of convenience, level of accuracy, level of clarity, and product suitability.

\section{1) Trial Design}

The trial design of this product is divided into two parts, namely expert evaluation and product testing. Expert evaluation is carried out by three people, each of whom is a material expert, media expert, and learning expert. While product trials were carried out in three stages, namely individual trials, small group trials, and field trials. Expert evaluation is carried out by taking questionnaire data in the form of questionnaires from material experts, media experts and learning experts. Determination of experts is based on competence and qualifications in the field of teaching. Furthermore, the results are analyzed and input is used as a basis for revising development products.

The product design trial is carried out by giving a test, and retrieving data in the form of a questionnaire, checks the list of users through the three stages that have been planned. The three stages are: (1) individual trial, (2) small group trials, and (3) field trials.

The product design trial was carried out using an experimental approach using a pre-experimental research design through one group pretest-posttest design, which was a study involving only one group of subjects. First of all, measurement of the variables is carried out before being given treatment, then the manipulation process is carried out by giving certain treatment to the research subject, then measuring the second time. According to Sugiyono "in the experimental study, there was treatment, while in naturalistic research there is no treatment [4]. Thus the experimental research method can be interpreted as a research method used to find out the influence of certain treatments on others under controlled conditions.

In this study, experiments were conducted with nonrandomized pretest-posttest of non-control group design. As stated by Wiyono that "the design of the preexperimental study was an experimental research design that only used the experimental group, without the control group. Subject samples were chosen without using randomization" [6].

The following is an experimental design picture used in the product development trial:

$$
\mathrm{O}_{1} \quad \mathrm{X} \quad \mathrm{O}_{2}
$$

Information:

$$
\begin{aligned}
& \mathrm{O}_{1}=\text { pretest } \\
& \mathrm{X}=\text { treatment } \\
& \mathrm{O}_{2}=\text { posttest }
\end{aligned}
$$

\section{(Source: Bonate [7])}

In the experimental design, the procedure that must be carried out is the determination of the schedule for giving pretest, treatment schedule and posttest administration schedule. Experimental steps or procedures are as follows: (1) pretest, (2) provision of treatment, and (3) posttest.

The pretest is given before the media is introduced. The pretest given is in the form of assignments using notation media that are commonly used. This is done to find out the initial condition of the subject, whether the common media notation can easily carry out and complete the task or vice versa. The treatment stage is carried out after the pretest is completed. Treatment is the introduction and teaching of color media notation resulting from development. The stage of giving the posttest is given in the form of assignment using color notation media that has been introduced and taught in treatment as a product development design while observing the performance process and seeing the final results of the assignment given. This stage is the T-test in the sample related.

This is done to find out the condition of the subject, whether before or after treatment there are differences, 
especially differences that are positive in the form of improvements in test results. Whether the color notation media can easily carry out and complete the task or vice versa. The final result of the development after the trial was a media product in the form of color notation for kindergartenaged children.

\section{2) Try Out Subject}

The subjects of this development trial are consist of need analysis and evaluation subjects. The subject of needs analysis is kindergarten students as users, which consists of (1) individual trial subjects are Al-Fadholi kindergarten students in Malang, (2) the small group trial subjects were 6 Al-Fadholi kindergarten children in Malang, and (3) the subjects of the field trial were 48 students from Al-Fadholi Kindergarten in Malang. Evaluation subjects consist of material experts, media experts, and learning.

\section{3) Data Type}

The type of data obtained is quantitative and qualitative data. Quantitative data obtained from questionnaires in the form of questionnaires containing statements or sentences, which will later be changed in the form of numbers. While the qualitative data is obtained from suggestions, responses, and input made during this development process.

\section{4) Data Collection Instruments}

The instrument used in the development of music notation media for these kindergarten-aged children is questionnaires in the form of questionnaires and list check results to measure all aspects related to the feasibility and effectiveness of the product through an assessment of the level of attractiveness, level of ease, level of accuracy, level of clarity, and level of suitability of the results development with research subjects. Questionnaires or interviews are used to collect data about: (1) needs analysis, (2) expert evaluation, assessment of the product design to be made, and (3) teacher's assessment/response about the development products that have been made.

\section{5) Data Analysis Techniques}

There are 2 techniques used in this study, namely descriptive qualitative data analysis techniques and descriptive/quantitative descriptive statistical analysis techniques in the form of percentages. Qualitative descriptive analysis techniques are used to process data in the form of suggestions and input, as well as the results of interviews obtained from experts and users. While quantitative descriptive analysis techniques are used to process data obtained from the results of trials on the subject of the user and expert validation. The results of data analysis are the basis for improving product development.

TABLE I. PERCENTAGE ClASSIFICATION

\begin{tabular}{|c|c|c|}
\hline No. & Percentage & Classification \\
\hline 1. & $76-100 \%$ & Very good / very valid \\
\hline 2. & $56-75 \%$ & Good / Valid \\
\hline 3. & $40-55 \%$ & Good enough / quite valid \\
\hline 4 & $>40 \%$ & Not good / invalid \\
\hline
\end{tabular}

(Adaptation from: Arikunto,[8])
To analyze quantitative data in this study used comparison formulas and percentages according to Sugiyono [4]. Before calculating the average results of the product being developed, an ideal score/criterion must be determined for the product development. To facilitate the interpretation or interpretation of the results of the percentage analysis used classifications as in Table 3.2 above.

Regarding the feasibility and effectiveness of music notation media for children of kindergarten age developed, a measure of validity of eligibility is determined if the aspects assessed on the product get a minimum score based on the table above. To determine the size of the effectiveness of the product other than based on the acquisition of a good minimum score, it is also seen from its function that can help children to memorize and read music notations and be interesting and can facilitate children in understanding music notation. Furthermore, after obtaining a score of feasibility and effectiveness, it can be determined how the level of validity of the product developed.

\section{RESULT AND DISCUSSION}

\section{A. New media that can help children memorize and read music notation}

Based on the results obtained, the following will review expert review data and data obtained from product trials related to the feasibility and effectiveness of the developed media notation. The expert review will be explained according to one material expert, one media expert, and one learning expert. While the trial data consisted of individual trials, small group trials, and field trials obtained from students of group B TK Al Fadholi, Lowokwaru.

\section{1) Discussion of Evaluation Data of Experts}

The design of technical notation media for kindergartenaged children has been evaluated by three experts consisting of material experts, media experts, and learning experts. According to experts, the developed music notation media is very feasible and effective to use. From the results of the evaluation data the experts showed the validity value of the developed music notation media scored a score of 54 with an ideal score of 60 . If calculated in the formula would get the following results. Based on the description of the data analysis above, material experts, media experts, and learning experts stated that the developed, feasible and effective media notation was used with a score of 54 and a percentage of $90 \%$ in the excellent category. These developmental media products can be said to be feasible and effective because they have met the assessed aspects by obtaining a good minimum score based on the validity classification table [8].

\section{2) Trial Data Discussion}

From the entire trial conducted to students of group B TK Al Fadholi Lowokwaru, the level of feasibility and effectiveness of development products to be used is known. From the data of the entire trial demonstrated the value of the validity of the media notation developed by a score as many as 109 , while the ideal score is 110 . If the count in the formula will be obtained the following results.

Based on the test result of data analysis, it can be stated that the media notation music for children ages kindergarten 
has been developed, it is feasible and effective to use with a score of 109 and a percentage value $99 \%$ in the excellent category. These developmental media products can be said to be feasible and effective because they have met the assessed aspects by obtaining a good minimum score based on the validity classification table [8].

To reinforce the above statement, the following is the result data of the comparison of pretest and posttest based on what has been done to the subject as a whole. Based on the data seen that before being given treatment, when conducted a pretest using existing notation media, the results of pretest obtained a score of 93 , while the ideal score for test results in the overall test is 110 . On the contrary, when the treatment was given and the posttest was done using the development notation media, the results obtained were 109 with an ideal score of 110. If calculated, the following results will be obtained.

From the comparison of pretest data and posttest data, it can be seen that the posttest results are higher than the results of the pretest. Based on the description of the data analysis above, it can be stated that the music notation media for kindergarten-aged children that has been developed, is very feasible and effective to use with a comparison of the pretest score of 93 percentages $84 \%$ and 109 posttest scores $99 \%$ in the very good category. This means that products that have been developed can help children memorize and read music notation. So for aspects of product feasibility and effectiveness, this development gets a very good minimum score based on the validity classification table [8].

\section{3) Discussion of Evaluation Data of Experts and Trials}

From the overall evaluation by three experts and three stages of trials conducted to students of group B TK Al Fadholi Lowokwaru, the level of feasibility and effectiveness of development products was known. According to experts and based on the results of the trial data it can be stated that the music notation media for children of kindergarten age is very feasible and effective to use. From the data from the evaluation of the experts and the results of the trial showed the validity value obtained a score of 163 with an ideal score of 170 . If calculated in the formula will get the following results.

Based on the description of the data analysis above, from material experts, media experts, learning experts, and test results it can be stated that the music notation media for kindergarten-aged children that has been developed, is very feasible and effective to use with a score of 163 and $96 \%$ percentage in the category very good. The music notation media resulting from this development can be said to be feasible and effective because it has fulfilled the assessed aspects by obtaining a very good minimum score based on the validity classification table. The product has fulfilled the elements of attractiveness, clarity, and convenience [9]. In addition, it can also be said that the media developed high achievability as a tool to achieve goals. An effective product is one that has high achievement in its objectives [10].

\section{B. Media new exciting and can facilitate a child to understand music notation}

Based on the results of the previous chapter relating to the feasibility and effectiveness of the media developed, the expert review will be explained according to one material expert, one media expert, and one learning expert. Whereas the trial data consisted of individual trials, small group trials, and field trials obtained from students of group B TK Lowokwaru in Malang.

\section{1) Discussion of Evaluation Data of Experts}

The design of technical notation media for kindergartenaged children have been evaluated by three experts consisting of material experts, media experts, and learning experts. According to experts, the developed music notation media is very feasible and effective to use. From the results of the evaluation data, the experts showed the validity value of the developed music notation media scored a score of 54 with an ideal score of 60 . If calculated in the formula would get the following results.

Based on the description of the data analysis above, material experts, media experts, and learning experts stated that the developed, feasible and effective media notation was used with a score of 54 and a percentage of $90 \%$ in the excellent category. These developmental media products can be said to be feasible and effective because they have met the assessed aspects by obtaining a good minimum score based on the validity classification table.

\section{2) Trial Data Discussion}

From the entire trial conducted to students of group B TK Al Fadholi, Lowokwaru, the level of feasibility and effectiveness of development products to be used is known. This can be seen from the results of the trial data as follows. From the overall results data, the trial shows the validity value with a score of 329 , while the ideal score is 330 . If calculated in the formula will get the following results.

Based on the description of the data analysis above, it can be stated that the music notation media for kindergarten-aged children that has been developed, is very feasible and effective to use with a score of 329 and a percentage value of $99 \%$ in the very good category. Product media the results of this development can be said to be feasible and effective because it has met the aspects assessed by obtaining a minimum score of very good based on the validity of the classification table.

To reinforce the above statement, the following is the result data of the comparison of pretest and posttest based on what has been done to the subject as a whole. Conversely, when the treatment has been given and posttest performed using notation media development results, the result 329 , with the score ideal for test results in the overall test is 330 . If calculated, the following results will be obtained.

From the comparison of pretest data and posttest data, it can be seen that the posttest results are higher than the results of the pretest. Based on the description of the data analysis above, it can be stated that the music notation media for kindergarten-aged children that have been developed, is very feasible and effective to use with a comparison of the pretest score of 299 percentage of $91 \%$ and posttest score of 329 percentage of $99 \%$ in the very good category. This means that the products that have been developed are interesting and can make it easier for children to understand music notation. So for aspects of product feasibility and effectiveness, this development gets a very good minimum score based on the validity classification table.

3) Discussion of Evaluation Data of Experts and Trials 
From the overall evaluation by three experts and three stages of trials conducted to students of group $\mathrm{B} \mathrm{TK} \mathrm{Al}$ Fadholi Lowokwaru, the level of feasibility and effectiveness of development products was known. According to experts and based on the results of the trial data it can be stated that the music notation media for children of kindergarten age is very feasible and effective to use. From the data from the evaluation of the experts and the results of the trial showed the validity value obtained a score of 381 with an ideal score of 390. If calculated in the formula, you will get the following results.

Based on the description of the data analysis above, from material experts, media experts, learning experts, and test results it can be stated that the music notation media for children of kindergarten age that has been developed is very feasible and effective to use with a score of 381 and a percentage of $98 \%$ in the very good. The music notation media resulting from this development can be said to be feasible and effective because it has fulfilled the assessed aspects by obtaining a very good minimum score based on the validity classification table. The product has fulfilled the elements of attractiveness, clarity, and convenience [9]. In addition, it can also be said that the media developed are high achievable as a tool to achieve goals. An effective product is one that has high achievement in its objectives [10].

Although in general the media notation products and techniques produced to meet the feasibility and effectiveness of validation and testing, in fact, the product has weaknesses that need to be addressed. The resulting product has problems when tested on subjects who suffer from color blindness. This is felt necessary by researchers to get attention as study material in more in-depth research.

The results of this development complement the theory of color beam notation. The fundamental difference between the concepts in this development and the Ottman theory is about the color function in notation. In Ottman's theory, color does not function as a substitute for tone or solmization but is used to show figures in musical notation [11]. For example, when there is a tone, for example, do the given symbol blue color (symbolizing is uncertain, depending on the determination maker notation), will be heading to the tone of sol given symbol red color, but before the tone sol, it turns out there is a "fa" tone as a trajectory, then the "fa" tone can be given a symbol with an easy orange or red color as a symbol that "fa" tone is a cross tone and has proximity to the sol tone. So the color symbol in Ottman's theory is not standard but based on the needs of the notation that will be symbolized.

\section{CONCLUSION}

After research and development of notation media for kindergartens (TK), through expert evaluations and product trials, it was concluded that the developed notation media fulfilled excellent feasibility and effectiveness. This is demonstrated by the acquisition of an overall score of 544 in the percentage of $97 \%$ with the ideal score is 560 . Based on the description can be elaborated that the evaluation of the data subject matter experts, media specialists, learning experts, and the results of product testing it in state media notation music for children of kindergarten age that have been developed, it is very feasible and effective used in very good categories.

Furthermore, as an amplifier, it can be stated that the music notation media for kindergarten age children that have been developed, is very feasible and effective to be used with a comparison of the overall pretest results, a score of 392 percentages $89 \%$ with an ideal score of 440 , and the overall posttest score 438 percentage points $99 \%$ with an ideal score of 440 . From the comparison of pretest data and posttest data, it is seen that the posttest results are higher than the results protest.

From the evaluation data of experts and the results of tests during product trials, it was concluded that music notation media for kindergarten-aged children developed can help children memorize and read music notation, besides that music notation media for kindergarten-aged children developed is also interesting and can make it easier for children to understand music notation.

\section{REFERENCES}

[1] G. E. McPherson, G.E., "From child to musician: Skill development during the beginning stages of learning an instrument," in Psychology of music, vol. 33(1), 2005, pp.5-35.

[2] M. Bassano, Healing with Music and Color: A Beginner's Guide. Weiser Books, 1992.

[3] K. E. Prier and K. Edmund. Ilmu Bentuk Musik. Yogyakarta: Pusat Musik Liturgi, 1996.

[4] M. P. Sugiyono, Pendekatan Kualitatif. Kuantitatif dan R\&D, Jakarta: Alfabeta. 2009.

[5] P. Setyosari, Metode Pengembangan Pendidikan dan Pengembangan. Jakarta: Kencana Prenada Media Group. 2013.

[6] B. B. Wiyono, "Penelitian Tindakan Kelas dan Penulisan Karya Ilmiah." 2008.

[7] P. L. Bonate, Analysis of pretest-posttest designs. Chapman and Hall/CRC. 2000.

[8] S. Arikunto, Prosedur penelitian suatu pendekatan praktik. Jakarta: Rineka Cipta. 2006.

[9] R. Susilana and C. Riyana, Media Pembelajaran: Hakikat, Pengembangan, Pemanfaatan, dan Penilaian. CV. Wacana Prima; 2008.

[10] S. Akbar, "Riset Pengembangan untuk Pengembangan Alat Pembelajaran." Makalah disajikan dalam Lokakarya Penyusunan Proposal Penelitian Didanai DRPM DIKTI, FIP UM, Malang. 2016 May, 2.

[11] P. Sheppard, Music makes your child smarter: peran musik dalam perkembangan anak. Gramedia Pustaka Utama; 2007. 